DOI: $10.2478 / \mathrm{v} 10025-010-0028-3$

\title{
The value of the water-protecting function of forests
}

\author{
Piotr GOLOS
}

Forest Research Institute, ul. Braci Leśnej 3, Sękocin Stary, 05-090 Raszyn, Poland; e-mail: p.golos@ibles.waw.pl

\begin{abstract}
The majority of forest characteristics related to a broadly understood water-protecting function of forests are the natural attribute of forest ecosystems. However, there are water-protecting forests and other woodlands whose natural ability to regulate water relations is intensified on account of public interest or forest management needs (costs are incurred to improve the quality and/or quantity of forests). In any of the above-mentioned cases, there is a need, particularly for the State Treasury-owned forests administered by the State Forests National Forest Holding (SF NFH), though for different reasons, to assess the value of water-protecting forest ecosystems.

A Contingent Valuation Method (CVM), or conditional valuation creating a quasi-market, enables in social surveys to assess and then valuate practically any kind of services forests provide to society, including the water-protecting one. The estimates made on the basis of the research conducted by the Forest Research Institute (IBL) in Warsaw using the CVM show that the value of this function is approx. PLN 86 million, or $9.40 \mathrm{PLN} \cdot \mathrm{ha}^{-1} \cdot \mathrm{year}^{-1}$.

The value obtained with the CVM appears to be over 10-fold lower than the value calculated on the basis of the costs of alternative goods having the attributes comparable to those of forest ecosystems. The IBL calculations taking exclusively into account the hydrological characteristics of forests indicate that their value set on the basis of the costs of construction and exploitation of retention reservoirs amounts to PLN 982 million (109.5 PLN $\left.\cdot \mathrm{ha}^{-1} \cdot \mathrm{year}^{-1}\right)$.

The water-protecting function of forests was found to be even more valuable using Marszałek's Relative Utility Value Method (WWU) in which the water-protecting function value for some part of protective forests serving this function was PLN 1177 million (805 PLN $\cdot h^{-1} \cdot$ year $^{-1}$ in the forests under the management of the SFNFH and $146 \mathrm{PLN} \cdot \mathrm{ha}^{-1} \cdot \mathrm{year}^{-1}$ in private forests).

The differences in the obtained findings are first of all the effect of divergent theoretical foundations and methodological assumptions of the presented valuation methods. Therefore, the attempts at implementing the selected social functions of forests in forest practice should be done with much prudence. It can be assumed that at the present stage of development of valuation methods, when research results arise many doubts, the decision to adopt any of the calculated values is a political one taken at national level or in exceptional cases when economic agreements are made - at regional level.

In the case of the public functions of forests, including water-protecting one, only this type of solutions may lead to the optimal regulation of the quality and quantity of this type of services.
\end{abstract}

Key words: alternative costs, Contingent Valuation Method, hydrological function of forests, questionnaire surveys 


\section{INTRODUCTION}

The forest function related to water protection is one of the multiple natural functions of forests defined as regulatory or, more often, protective. They accompany the forest ecosystem regardless of its ownership category or its management and natural status. This is in line with the so called "keelwater theory". According to this theory, even if the forest management regime is totally subordinated to the productive function, execution of other functions, including water protection, will always take place to a certain degree. And vice versa, in forests whose main task is maximized implementation of selected public functions (e.g. water conserving forests, soil conserving forests, or forests designed for leisure and recreation), the productive function of forests will always be exercised to a certain degree (KLOCEK and PŁOTKOWSKI, 1998).

Quite often, under specific circumstances due to the characteristics of the socio-economic environment or natural conditions, forest management must enhance the quantity and/or quality of public services incurring the costs of their implementation. In such a case, a cost-benefit analysis should be made, that is to say the total value of outlays and the real or potential benefits should be estimated. On the basis of such analysis, in which the value of public functions of forest management is a necessary component, it is possible to measure the economic effectiveness of the undertaken actions. However, an attempt at even an approximate economic value of such goods meets with difficulties already at the stage of their estimation in natural units (e.g. $\mathrm{m}^{3}$ of water per ha, or $\mathrm{mm}$ of precipitation per $\mathrm{m}^{2}$ ) connected with distinguishing clearly two kinds of effects related to the nonproductive functions of forests, as these can be treated as (BLUM et al., 1996):

- natural attributes of forests which are not enhanced by any planned human action - they exist because the forest ecosystem exists, regardless of its natural or management status,

- "rational forest management effects", which are intensified in an intended and planned way, connected with the need to incur certain expenses, to sacrifice part of the income and accept losses related to their use which affect the volume of revenues from the sale of timber raw materials.

From the economic point of view, in the first case we deal with the positive effect of a forest ecosystem which by no means affects the forest management status or is dependent on it. Such a situation is frequently observed in private forests in Poland, where the owner of a small forest estate (average forest area in an agricultural farm take up 1.3 hectares) does not undertake any forest works associated with intensification of the non-wood forest functions (lack of financial mechanisms encouraging this type of activity). If he finally undertakes forest works, his intention is to enhance the quality or quantity of timber raw materials; this of course does not preclude at least a minimum degree of positive effect of his economic activity in the scope of selected public functions of forests. 
In the second case it should be admitted that there are positive external effects of forest management. These are the unintentional effects (results) of the economic process which influence the level of consumer and producer utility (Ekonomia..., 1996). In extreme cases, these become the main target of forest management, and timber raw materials on which its economic existence is based become an external effect of the non-wood goods and services provided. In such a situation, the public goods and services should be treated as market goods (should be marketed), although their properties still determine their public nature. Such a situation occurs e.g. in the reserves of the State Forests National Forest Holding (State Forests NFH) where ecological functions (nature conservation) determine the level of execution of the productive function of forests - production of timber raw materials.

The difficulties with the opening of the market for public goods and services of forests and forest management are connected not only with the nature of these goods, but also with the current legal regulations in Poland (unlimited, free access to State Treasury-owned forests and the goods and services provided by them, with the exception of timber and game animals), as well as the economic and social conditions (the natural attributes of forests, as well as the public services of forest management are not subject to sale - it is difficult to set clear-cut criteria enabling separation of timber production costs from intensification of the non-productive functions of forests, which might be the basis for valuation).

Despite the above-mentioned difficulties in valuating these services, attempts should be made at seeking the methods of assessing their economic value which is essential to forest management for at least two reasons:

1) for obtaining full economic calculus of forest management in the conditions where expenses related to the execution of the public functions of forests influence the economic effects of a forest estate (possibility of comparing expenses and alternative methods of allocating public funds),

2) for estimating the real share of the forest sector in the creation of the Gross Domestic Product (GDP) (the need to take into account all costs and benefits, including social - external effects).

The starting point for establishing the value of this type of goods and services can be:

- scarcity of goods - an economic category enabling valuation in accordance with the Marginal Utility Theory,

- the costs of production of a valuated good or its replacement by substitute goods (real and alternative costs) which are justified as the basis of valuation in the Labour Theory of Value,

- this good's ability to generate revenues, which means that its value is connected with its potential to provide a rent to its owner, so the valuation methods refer to the Rent Theory known in forestry (forest and land rent). 
The theoretical basis of valuation of the public goods and services of forests and forest management enables seeking the methods of estimating the value of the water-protecting function of forests among three groups of methods on the basis of:

1. Analysis of incurred costs of intensification of the natural forest abilities to conserve and protect against water taking into account reduced revenues of a forest estate caused by a change in the most important stand parameters, such as age, assortment structure or volume of harvested timber.

2. Alternative costs that should be incurred for the production or daily operation of the equipment, building and engineering structures that would perform a role similar to forests (substitute goods with attributes similar to those of the forest ecosystem, if this is possible).

3. On the basis of the Quasi Market Valuation System, where usefulness of a good for the consumer determines the value of that good which has no market value (such utility is expressed in consumer satisfaction with his basket of consumed goods). The user/consumer sets the value to a non-market good by declaring a hypothetical amount of money he is willing to spend to use this good on recent terms (economists maintain that the maximum amount which individuals are ready to pay for enhanced availability, quality or quantity of a certain environment service is a fair estimation of its economic value - the price (Ekonomia..., 1996)).

In the presented publication, the theoretical and methodological assumptions, as well as the results of estimation of the water-protecting function of forests using two valuation methods are depicted:

1) Contingent Valuation Method (CVM) which, in its assumptions, refers to the Marginal Utility Theory.

2) Professor Marszałek's method of Relative Utility Value which belongs to the so-called indicative valuation methods.

The presented calculation of an appraisal value of the water-protecting services of forests is preceded by a short description of the development of the Theory of Value and by the chapter dealing with the most important issues related to enhancement, use and valuation of the non-productive functions of forests.

\section{VALUE CATEGORIES IN THE DEVELOPMENT OF ECONOMIC THOUGHT}

Different definitions and categories of value have appeared throughout the history of economics. In Antiquity, Aristotle differentiated between utility value and exchange value. In the Middle Ages, discussions were held on the objectivity of a thing which decided about its usefulness and which in conjunction with scarcity created the value of a good in relation to the degree of satisfaction of human needs by it. A new approach to the sources of value was introduced by classical economists. Ricardo (1817) and Marx (1867) showed that the value of a good is related to the labour needed to produce it. This viewpoint was then verified by neoclassical 
economists who introduced the term utility of a good. It gave birth to the Subjective Theory of Value in which the Final Utility Theory played a major role. Its beginning should be sought in an attempt at the explanation of Smith's paradox of value - the things which have the greatest value in use have frequently little or no value in exchange; and on the contrary, those which have the greatest value in exchange have frequently little or no value in use.

Research on the theoretical foundations of valuation brought fruits at the beginning of the 1950s in the form of a Preference Theory of Value. The assumptions of this theory were developed in response to the aforementioned drawbacks in the Objectivist Theory of Value (value $=$ labour) and Subjectivist Theory of Value (value = utility).

The authors of the said theories attempted to assess the real value, rejecting the assumptions by which the value of a good is its attribute (Objectivist Theory), or that it depends on the individual taste of a valuating person (Subjectivist Theory). According to the Preference Theory of Value, the value of a good is its ability to surpass another good in a situation when the aim function and the effect are the factors determining that value; this pertains both to the objects and ways of acting. The value exists regardless of the persons and things involved in the valuation process. Building a forest road across a large forest complex can exemplify two competitive value systems. Such an investment has a positive value from the point of view of economic effects, as it shortcuts the distance of transported timber. It can at the same time have a negative value from the point of view of nature conservation. The drawback of the said theory is lack of the possibility to systematize the very values. Unlike in the Subjectivist and Objectivist Theories, here it is not possible to distinguish value categories, as they can be classified as objective or subjective values depending on the circumstances of the valuation process.

It can be said that the presented value theories exhaust at the present stage the main directions of investigations into the sources or measures of value. The first (objectivist) of the presented theories is in fact a historical one, though it still plays an important role as concerns the methods of assessing stand losses and values. The subjectivist method is obligatory in the market economy and constitutes the theoretical basis of the Contingent Valuation Method. The last of the described theories is the latest one and is in the development phase.

\section{THE ECONOMIC ISSUES RELATED TO THE NON-WOOD FOREST FUNCTIONS}

The interest in the economic aspects of the non-productive functions of forests throughout the history of forestry falls on the contemporary times and results from the fact that till the middle of the $18^{\text {th }}$ century forests had not been managed. Only under the influence of economics, the forest estate came under the focus of econo- 
mists, however still to an insufficient degree; it was in the first place treated as a source of tax revenues (national product growth) (KLOCEK, 1998).

In classical economics, mainly under the influence of Smith's economic views (1776), the forest was regarded as an investment in which the input capital was to generate a definite income (rent). In spite of this approach, the importance of the non-productive functions of forests for human environment's ecological equilibrium was for the first time given attention. Unfortunately, the values of supply for these functions were not linked with the necessity of incurring additional expenses by a forest estate. Only Mill's works (1848), as well as the later output of neoclassical economics, with Marshall as its key representative (1890), provided theoretical foundations for the analysis of the non-wood forest functions as public goods, as well as external effects, that is goods for which, as Wicksell wrote in his work on finance "Finanztheoretische Untersuchungen (1896), "market mechanisms are not able to reveal consumers' propensity to articulate preferences for this kind of goods (public goods)" (BLAUG, 1994). During that time, economists and foresters in Poland focused their attention first of all on the protective functions of forests, particularly the one related to water-protecting, which was reflected e.g. in the Austrian Forest Act of 1852 which was in force at that time in the Polish territory (Forest Act..., 1887) and the 1888 Russian Act on forests in the Polish Kingdom (LESIEWSKI, 1912).

Fulfilment of the public tasks of forests at the end of the 19th century is to a large degree the result of neo-liberal economics also called Economics of Welfare, in which attention was for the first time focused on the qualitative aspects of lives of individuals and communities (KLOCEK, 1999). However, before the nonproductive functions of forests had been considered economic goods of forest management, those functions were long (till 1970) believed to be quasi automatic or by-effects of standing timber production. It was assumed that their execution had no influence on the amount of net income of a forest estate. Today we know that it is not true, as three groups of costs like additional costs for their intensification, losses related to the application of different management systems, as well as losses caused particularly by the use of the social functions of forests (e.g. recreation) render it impossible to regard such forest services as positive external effects of forest management. If this by any chance is the case, it is so only from the user's point of view, never from the point of view of forest management paying the involved costs.

The consequences of the said situation are varied. In most cases the theoretical and methodical problems have been solved only partially. One of more important seems to be the task to seek the methods of valuation (value categories and economic measures) of the public functions of forests (FAMIELEC, 1999). It is difficult, as the non-wood forest goods are free of charge from the consumer's point of view (demand), while from the forest estate's point of view (supply) these are economic goods which involve certain outlays on the part of the forest estate. In the case of 
forest management carried out by the State Forests NFH (covering its expenses with revenues mainly from the sale of timber raw materials), already today we have a situation that part of the costs related to the non-productive functions of forests are hidden in timber prices. Therefore, a question arises whether it is fair from the point of view of the entities dealing in the timber sector that they have to finance to some extent the public functions that should be financed by the State. It is the situation which was referred to in a fragment taken from the $19^{\text {th }}$ century Polish literature that "... no other institution but the Government itself should act in support of the public benefits of forests" (JANCZEWSKI, 1840). The more so, that only the State has at its disposal adequate mechanisms to prevent a situation of excessive consumer demand for and use of the public functions of forests that would be different if only "symbolic" charges were introduced.

As it is not possible to measure in a direct way the utility of every good and set market prices for the public functions of forests, the above mentioned difficulties have directed efforts on seeking such valuation methods that would reveal the "quasi-market" value of the non-wood forest goods. The methods allowing substitution of the market mechanism in the case of public services of forest management, used with different success, serve this purpose. Their essence is the valuation of the non-wood forest goods on the basis of the satisfaction (utility) which users (consumers) derive from them. Most frequently applied is the Contingent Valuation Method - CVM, where hypothetical or substitute market mechanisms (market substitute) are used to successfully assess the value of practically any public good, including forest goods provided to society. The value of an appraised good is the amount of money revealed in questionnaire surveys (PLN/year/person or PLN/year/household) which respondents are willing to pay for keeping the quantity and/or quality of the valuated good at the same level (Willingness To Pay - WTP), or the amount the users would accept should the quantity and/or quality of the valuated good be decreased or deteriorated (Willingness to Accept - WTA). The methodological assumptions of this valuation method have their source in the Subjective Theory of Value (market attributes) which, in accordance with the direction of development of the contemporary economic, social and philosophical thought, points to, "... gradual elimination of labour from the central place it occupied in modern capitalism" in favour of "consumer freedom" with its central principle of satisfaction from buying and consuming any kind of good and service (BAUMAN, 1992). This statement clearly indicates the direction of the efforts focused on seeking the valuation methods whose theoretical foundations would be based on the assumptions of the Subjective Theory of Value. 


\section{ASSESSMENT AND VALUATION OF THE WATER CONSERVING FUNCTION OF FORESTS ON THE BASIS OF OPINION POLLS - THE CVM WITH THE WTP INQUIRY PATTERN}

The CVM is one of the most frequently applied methods of valuating the public functions of forests (MCKENNEY and SARKER, 1994; MORTON et al., 1995). The assumptions of the discussed method were formulated by S.V. Ciracy-Watrup in 1947, and its improved version was presented in 1963 by R.K. Dawis (BERGEN, 1991; 1994). It was for the first time applied in 1957 for valuating recreational benefits of the Delaware River basin in the USA (BATEMAN et al., 1996b). The reviewed method is recommended in the USA by the US Water Resources Council (1979) (LOOMIS and GONZALES-CABAN, 1998) as a technique useful for assessing the benefits derived from the recreational use of the environment (ROSENTHAL and WALSH, 1986). It is also acknowledged by U.S. courts of law as a justified and recognized procedure of valuating environmental elements (GEORGIOU, 1996).

The Contingent Valuation Method for assessing changes in consumer utility in terms of money uses Hicks' rents, i.e. the amounts of money balancing or compensating changes at consumer utility level. A change in utility level can be caused by a fall or rise in price/quantity, and the consumer may respond in two ways: is willing to pay a defined amount (in WTP) or accepts compensation (WTA) (BATEMAN et al., 1996b).

To assess the pecuniary value of a non-market good, respondents are given in the offered socioeconomic questionnaires a scenario of hypothetical changes in the quantity and quality of the valuated good. In practice, the respondents are asked to set the amount of money they are willing to pay from their own budgets for not introducing changes that would reduce the utility level or for retaining the existing consumer utility level (value of Willingness To Pay - WTP), or the amount of compensation to the user (consumer) for the reduction or retaining the low utility level (value of Willingness To Accept - WTA). The thus assessed values of WTP and/or WTA correspond to the consumer's surplus - values of valuated good (GEORGIOU, 1996). By balancing losses and benefits a change in the quantity and/or quality of natural environment goods may cause (change in the level of the recently achieved utility), the respondent estimates the amount of WTP and/or WTA, thus setting the pecuniary value of a non-market good in the same way as if a real market for that good existed.

The advantage of the CVM pointed to in literature, at least in theoretical and methodological assumptions (OPALUCH, 1996), is an attempt to assess the value which the non-market forest goods would reach if they were sold in real market transactions. Its knowledge (willingness to pay and amount of compensation) creates the possibilities of seeking such political solutions that would enable financing of the growing public demand for the non-productive functions of forests (BERGEN, 1991). The justifiability of such expectations can be found in a quotation 
from Mill who already in 1848 wrote in his "Principles of Political Economy"... "there are spheres where law must intervene, not to disturb individuals in pursuing their own interests, but to make these possible: they can reach this goal only by community consent, however this consent attains real meaning when it is approved and sanctioned by law “(BLAUG, 1994).

In the following study, the WTP inquiry format is used. The value of the water-protecting function of forests is calculated based on the results of assessment and valuation of the non-productive functions of forests carried out in countrywide representative surveys. For comparison, results of the assessment of the waterprotecting function of forests against the selected most important public functions of forests performed in detailed surveys at diversified natural sites and on sample respondents of different socioeconomic characteristics are presented.

\section{ASSESSMENT OF THE PUBLIC IMPORTANCE OF THE WATER-PROTECTING FUNCTION OF FORESTS AS THE BASIS FOR SETTING ITS ECONOMIC VALUE IN THE CONTINGENT VALUATION METHOD (CVM)}

In the studies carried out by the IBL in 1998-2008 using the CVM, the waterprotecting function of forests was never subjected to a thorough economic analysis. The water-protecting services of forests and forest management were one of the multiple selected public functions of forests which were submitted for public evaluation and then for assessment of their economic value using the inquiry about the WTP in the CVM.

Presented results of assessment of the economic value of the water-protecting function of forests are based on the countrywide representative surveys commissioned by the IBL and carried out by the Centre for Public Opinion and Broadcasting Research (OBOP) in 2000. The randomly selected representative sample group of Poland's inhabitants assessed, in questionnaire surveys, the importance of the public functions of forests giving answers to the following question: How much important to natural environment do you think are the following non-wood forest tasks and factors?

In practice, respondents were to distribute 100 points among the six nonproductive functions of forests listed in the question, including the water-protecting function. In answer to the question, respondents ranked the importance of the nonwood forest functions, by assigning points.

Among the six public functions of forests, the water-protecting function was ranked 5. The respondents assigned it 11.5 points (Table 1, col. 2). The most important indicated function related to air cleanness protection scored nearly 28 points on average. The results of the representative country-wide surveys assessing the most important public functions of forests (OBOP, 2000) were then confirmed 


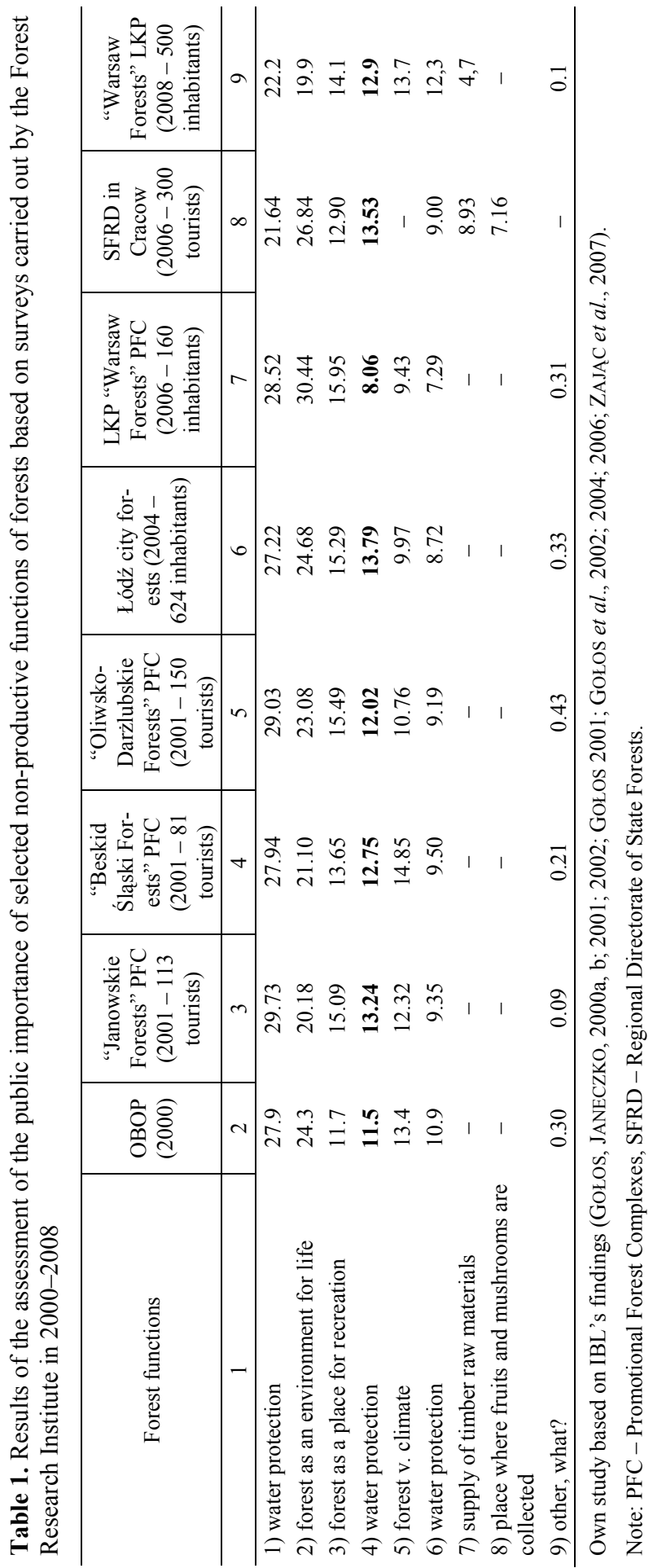


in many detailed surveys at various forest sites of the State Forests NFH (Promotional Forest Complexes) (Table 1, col. 3-9 - the year of survey and size of sample are given in parentheses)

The findings show that there is a permanent hierarchy of surveyed functions in public awareness. The importance of the water-protecting function of forests expressed in the number of assigned points oscillated from 11 plus to nearly 14 points in the space of eight years at different forest sites, except for the Promotional Forest Complexes - Warsaw Forests (2006) where the water-protecting functions of forests scored over 8 points on average.

\section{VALUATION USING THE CVM AND THE WTP INQUIRY FORMAT}

Having obtained the above-mentioned data concerning the importance of the water-protecting function of forests (country-wide surveys OBOP 2000), it is possible to calculate its estimated value on the basis of hypothetical declarations of respondents. The theoretical assumptions of the CVM show that in answering this question respondents should declare a certain amount of WTP for retaining the current level of total utility which is also influenced by the level of execution of all or selected non-productive functions of forests.

The countrywide surveys have proved that less than half the respondents would be willing to incur any expenses related to the non-productive functions of forests. This is very important practical information, as if a referendum were to be held about the introduction of charges for the use of the public services of forests, its results would be negative for forest management.

In an attempt to valuate the water-protecting function of forests for Poland's population on the basis of assessment of the importance of selected non-productive functions of forests and their economic value based on the amount of WTP $>0$ declared by a representative country-wide random sample group, the following assumptions were adopted:

1) the calculations assumed generalization of the findings for all Poland's inhabitants over 15 years of age $-30,714$ thousand persons,

2) the average value of the WTP obtained in the survey was transferred only onto that part of the population who in the questionnaire declared the amount of the WTP $>0$ (lack of declaration or declared WTP $=0$ were treated as refusal to cofinance the non-productive functions of forests, including the water conserving one) - the proportion of respondents in a sample group who were willing to cofinance the whole complex of non-productive functions of forests amounted to $46.49 \%$,

3) the differences in the values of WTP amounts depending on social or economic characteristics of respondents were omitted in the calculations, using the arithmetic mean for all cases of WTP $>0-52 \mathrm{PLN} \cdot \mathrm{ha}^{-1} \cdot \mathrm{year}^{-1}$, 


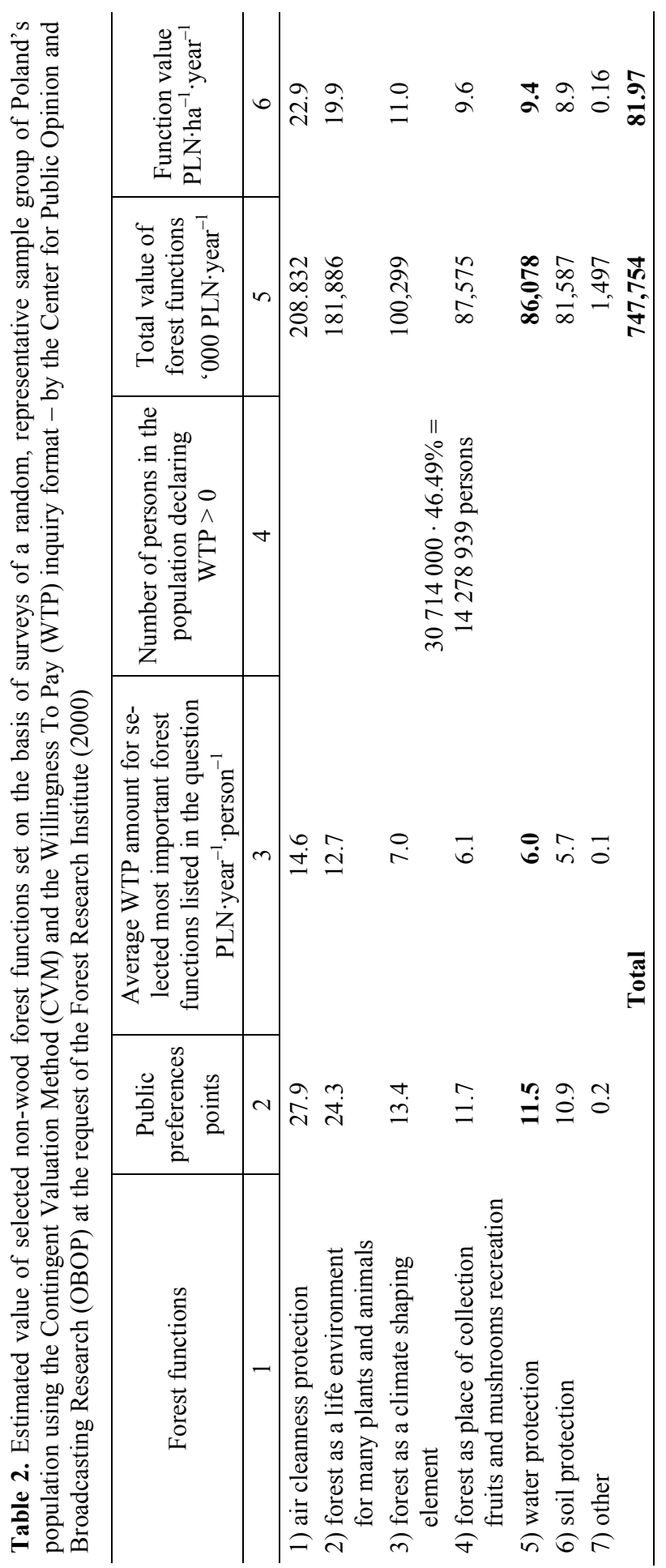


4) it was assumed that part of the declared WTP amount set on the basis of the importance structure of the valuated functions would be the value of the waterprotecting function of forests - the importance of the water-protecting function expressed in the average amount declared by respondents amounted to 11.5 assigned points.

The estimated value of the proposed public functions of forests amounted to nearly PLN 748 million, of which over PLN 86 million for the water-protecting function of forests. In calculating the value of the water-protecting function of forests per unit of forest area (8 864.8 thousand hectares, 2000), one hectare of forest provides services valued PLN 9.40. If we take into account only the area of the state-owned forests administered by the State Forests NFH (6953.0 thousand hectares - Forestry 2001), the value of water-protecting function would increase to 12.37 PLN $\cdot \mathrm{ha}^{-1} \cdot \mathrm{year}^{-1}$. If only the area of water-protecting forests was taken into consideration (1,155 thousand hectares - Forestry 2001), the value of this type of function would amount to $74.41 \mathrm{PLN} \cdot \mathrm{ha}^{-1} \cdot \mathrm{year}^{-1}$.

\section{RELATIVE UTILITY VALUE - PROFESSOR MARSZAŁEK'S METHOD}

The assumption of the method which is also referred to as expert or Delphian was developed by Professor T. MARSZAŁEK (1993a,b). The method establishes the preference structure for selected non-productive functions of forests on the basis of questionnaire surveys. The selected sample group rates them by assigning points. On the basis of the score, function values are assessed using values of the base function which is the timber raw material productive function expressed as timber sales revenue per hectare in a year.

The value of the non-productive functions of forests in the WWU method is assessed on the basis of the value of production of the main market good of forest management (timber raw material) and subjective assessment of the importance of selected forest functions.

Having obtained the results of public assessment of the above mentioned functions expressed in points and the pecuniary (market) value of production of the base function ( $\mathrm{PLN} \cdot \mathrm{ha}^{-1} \cdot \mathrm{year}^{-1}$ ), it is possible to set the pecuniary value of individual functions in accordance with the following formula:

$$
P F_{x}=\frac{P F_{b}}{F_{b}} F_{x} O_{x}
$$

where:

$P F_{x}$ - value of products and services obtained from function $x, \mathrm{PLN} \cdot \mathrm{ha}^{-1} \cdot \mathrm{year}^{-1}$,

$P F_{b}$ - value of products and services obtained from the base function being the source of a so-called reference value, PLN $\cdot h^{-1} \cdot$ year $^{-1}$, 
$F_{b}$ - relative utility value of products and services obtained from the base function being the source of the so-called reference value, point $\cdot \mathrm{ha}^{-1} \cdot \mathrm{year}^{-1}$,

$F_{x}$ - relative utility value of products and services obtained from function " $x$ ", point $\cdot \mathrm{ha}^{-1} \cdot$ year $^{-1}$,

$O_{x} \quad$ - area of forests performing a given type of function, ha,

$x \quad-$ individual function types.

To assess and valuate the whole set of selected public functions of forests, including water conserving one, the results of the assessment and valuation of the importance of these functions in questionnaire surveys carried out in 2005 by the IBL in the territory of the Regional Directorate of the State Forests in Cracow were used. The following assumptions were adopted in assessing and valuating the importance of the water-protecting function of forests:

1. The value of the water-protecting function of forests was assessed separately for the forests administered by the State Forests NFH (7 030 thousand hectares) and for private forests (1 573 thousand hectares) - status as of 31.12.2004.

2 . In the valuation process it was assumed that the value of the protective functions of forests would be assessed only for forests performing defined protective functions. Only in the case of the timber production and non-productive functions, the area of all forests of the State Forests NFH and privately-owned will be taken for valuation.

3. Preferences concerning private forest functions are identical as in the case of the forests administered by the State Forests NFH.

4. Value " 1 " of a point is calculated on the basis of public preferences established in questionnaire surveys for selected forest functions and the value of production of timber raw materials. In the case of the forests of the State Forests NFH, the value amounted to:

$$
\text { 531.96 PLN/8.93 points }=59.57 \mathrm{PLN}
$$

In the case of privately-owned forests, the value amounted to:

$$
\text { 91.44 PLN/8.93 points }=10.80 \mathrm{PLN}
$$

On the basis of the above mentioned data, the total value of the nonproductive functions of forests administered by the State Forests NFH amounted to PLN 2709 million - 4,995 PLN $\cdot \mathrm{ha}^{-1} \cdot \mathrm{year}^{-1}$. The value of the water-protecting functions of the water-protecting forests administered by the State Forests NFH and privately-owned is set in the WWU method at PLN 1177 million (684 $\left.\mathrm{PLN} \cdot \mathrm{ha}^{-1} \cdot \mathrm{year}^{-1}\right)$. Due to a great difference in the value of production of timber raw materials in the state-owned and privately-owned forests, the value of waterprotecting functions also differed remarkably. In the state-owned forests, the value of the water-protecting function amounted to $805 \mathrm{PLN} \cdot \mathrm{ha}^{-1} \cdot \mathrm{year}^{-1}$, while in the privately-owned forests only to $146 \mathrm{PLN} \cdot \mathrm{ha}^{-1} \cdot \mathrm{year}^{-1}$. 
Contrary to the general opinion that the CVM overestimates the value of the appraised good, the lowest value of the water-protecting function of forests (PLN 1177 million $-684 \mathrm{PLN} \cdot \mathrm{ha}^{-1} \cdot \mathrm{year}^{-1}$ ) was obtained using this method. Significantly higher values were obtained with the method in which cost analysis of the construction and operation of storage reservoirs, performing a similar function to forests was used for assessing the hydrological function of forests. The estimated value of the hydrological function of forests is over 10-fold higher that that set in the CVM (PLN 982 million and $109 \mathrm{PLN} \cdot \mathrm{ha}^{-1} \cdot \mathrm{year}^{-1}$ ). The highest value of the water-protecting function of forests was obtained using the WWU method in which only water-protecting forests were assumed to perform this function (PLN 1177 million - $684 \mathrm{PLN} \cdot \mathrm{ha}^{-1} \cdot \mathrm{year}^{-1}$ ).

Interesting is the comparison of selected real costs of intensification of the non-productive functions of forests with the value of the water-protecting function of forests. Assuming that the work performed in the territory of the Regional Directorate of the State Forests in Cracow (GoŁOs et al., 2006) has the same intensity as that performed in the territory of the forests administered by the State Forests NFH, the value of incurred costs would amount to PLN 193 million, or approximately 27 PLN $\cdot h a^{-1} \cdot$ year $^{-1}$.

\section{SUMMARY}

The above calculations are approximate values only, however, they show the economic importance of selected public functions of forests, including, in a greater detail, the water-protecting function. Each of the methods has diverse theoretical and methodological bases; hence the obtained results are much diversified (however they should be similar because a specific good at a given moment and under defined conditions has one value). This certainly is a big disadvantage of the applied methods; however its source is not in the methods but in the attributes of the public goods and services of forests and forest management.

From the theoretical point of view, the value closest to the generally accepted one, should, given the correctly planned and conducted surveys, be that set by the CVM using the WTP format (9 PLN $\cdot \mathrm{ha}^{-1} \cdot \mathrm{year}^{-1}$ ).

From the point of view of analytical possibilities and inclusion of the assessed value in the economic calculus of forest management, the non-productive functions of forests set on the basis of incurred costs for their maintenance and intensification (27 PLN $\left.\cdot \mathrm{ha}^{-1} \cdot \mathrm{year}^{-1}\right)$ seem to be appropriate. The method of valuating the waterprotecting function of forests on the basis of substitute costs - construction of storage reservoirs for assessing the value of the hydrological function of forests - creates similar possibilities (109 $\left.\mathrm{PLN} \cdot \mathrm{ha}^{-1} \cdot \mathrm{year}^{-1}\right)$.

The results of the WWU method (indicative), in which the value of timber raw material production $\left(684 \mathrm{PLN} \cdot \mathrm{ha}^{-1} \cdot \mathrm{year}^{-1}\right)$ is a reference point for assessing the wa- 
ter protecting and other selected forest functions, have the least to do with real value.

\section{REFERENCES}

1. BAteman I.J., LANGFord I.H., Willis K.G., TuRner R.K., GARROD G.D., 1996b. Wpływ stosowania wyboru dwudzielnego, wielokrotnej licytacji i formatów pytań otwartych w badaniach wyceny warunkowej. W: Ekonomiczna wycena środowiska przyrodniczego. Red. G. Anderson, J. Śleszyński. Białystok, Wydaw. Ekon. Środ.: 147-179.

2. BAUMAN Z., 1992. Socjologia i ponowożytność. W: Racjonalność współczesności. Warszawa, PWN.

3. BERGEN V., 1991. Towards the theory of monetary evaluation of social functions of forests. Monetare Bewertung landeskulturellen Leistungen der Forstwirtschaft - Beitrage zum Symp. Göttingen. Frankfurt am Main, J.D. Sauerlander's Verlag.

4. Bergen V., Friese Ch., 1994. Entwicklung eines Fragebogens im Rahmen der Bedingten Bewertungsmethode (Contingent Valuation Method) zur monetaren Bewertung der Erholungsfunktion des Waldes. Zur Wertschätzung der Infrastrukturleistungen des Pfalzerwaldes. Mitteilungen aus der Forstlichen Versuchsanstalt Rheinland - Pfalz: 73-111.

5. Blaug M., 1994. Teoria ekonomii. Ujęcie retrospektywne. Warszawa, PWN.

6. Blum A., Brandl G., Oesten G., Ratz T., Schanz H., Schmidt S., Vogel G., 1996. Wohlfahrtsökonomische Betrachtungen zu den Wirkungen des Waldes und den Leistungen der Forstwirschaft. Allgemaine Forst Jagdezeit., 5: 89-95.

7. Ekonomia środowiska i zasobów naturalnych, 1996. Red. H. Folmer, L. Gabel, H. Opschoor. Warszawa, Krupski.

8. FAMIELEC J., 1999. Straty i korzyści ekologiczne w gospodarce narodowej. Warszawa-Kraków, Wydaw. Nauk. PWN.

9. GoŁos P., 2001. Wycena wartości ekonomicznej rekreacyjnej funkcji lasu na przykładzie Leśnego Kompleksu Promocyjnego Gostynińsko-Włocławskiego. Warszawa, SGGW PhD-Thesis.

10. GoŁOS P., JANECZKO E., 2000a. Potrzeby społeczne w zakresie pozaprodukcyjnych (publicznych) funkcji lasu, żródła ich finansowania oraz konsekwencje dla gospodarki leśnej na przykładzie wybranych regionów kraju. Dokumentacja naukowa. Warszawa, IBL.

11. GoŁos P., JANECZKo E., 2000b. Pozaprodukcyjne funkcje lasu i źródła ich finansowania w opinii Polaków. Badania opinii publicznej OBOP. W: Potrzeby społeczne w zakresie pozaprodukcyjnych (publicznych) funkcji lasu, źródła ich finansowania oraz konsekwencje dla gospodarki leśnej na przykładzie wybranych regionów kraju. Dokumentacja naukowa. Warszawa, IBL.

12. GoŁos P., JaneCZKo E., 2001. Las i jego funkcje w opinii Polaków. Badania opinii publicznej OBOP. W: Modelowe zagospodarowanie lasu dla rekreacji i wypoczynku w wybranych LKP - badania opinii publicznej. Dokumentacja naukowa. Warszawa, IBL.

13. GoŁos P., JANECZKO E., 2002. Modelowe zagospodarowanie lasu dla rekreacji i wypoczynku w wybranych LKP - badania opinii publicznej. Dokumentacja naukowa. Warszawa, IBL.

14. GoŁos P., Zaperty E., Kaliszewski A., Laskowska K., GeszPrych M., Hildebrnd R., 2004. Gospodarka leśna na terenach zurbanizowanych. Dokumentacja naukowa. Etap I. Warszawa, IBL.

15. GoŁOS P., KALISZEWSKI A., 2006. Analiza porównawcza metod oceny i wyceny pozasurowcowych funkcji lasu na przykładzie reprezentatywnego obiektu w Polsce. Dokumentacja naukowa. Warszawa, IBL.

16. JANCZEWSKI, 1840. O wpływie lasów. Sylwan, 16: 313-325.

17. KLIMCZAK B., 1995. Mikroekonomia. Wrocław, Wydaw. AE.

18. Klocek A., PŁotkowski L., 1998. Las i jego funkcje jako dobro publiczne. W: Las, człowiek, przyszłość. Materiały i dokumenty. T. 2. Kongres Leśników Polskich. Warszawa. 
19. KLOCEK A., 1998. Pozaprodukcyjne funkcje lasu - dobra publiczne gospodarki leśnej. Sylwan, 11: $5-20$.

20. KLOCEK A., 1999. Pozaprodukcyjne funkcje lasu jako publiczne świadczenia gospodarki leśnej oraz stan jej równowagi. Sylwan, 12: 5-20.

21. LeSIEWSKI J., 1912. Przepisy prawne w lasach Królestwa Polskiego. Wyd. Z.

22. MCKenNEY D., SARKER R., 1994. An overview of non-wood valuation efforts in Ontario. Forestry Chronicle, 1: 47-54.

23. MARSZALEK T., 1993a. Względna wartość użytkowa produktów i usług uzyskiwanych dzięki gospodarczym i socjalnym funkcjom lasu. Sylwan, 9: 5-13.

24. Marszalek T., 1993b. Pieniężna ocena dóbr powstających dzięki socjalnym funkcjom lasów grupy pierwszej państwowego gospodarstwa leśnego. Sylwan, 8: 5-13.

25. Morton K.M., AdAMOWiCZ W.L., Boxall P.C., 1995. Economic effects of environmental quality change on recreational hunting in northwestern saskatchewan: a contingent behaviour analysis. Can. J. Forestry Res., 25: 912-920.

26. OpaluCH J.J., 1996. Rynkowe metody wyceny ekonomicznej. W: Ekonomiczna wycena środowiska przyrodniczego. Red. G. Anderson, J. Śleszyński. Białystok, Wydaw. Ekon. Środ.: 14-35.

27. Rosenthal D.H., Walsh R.G., 1986. Hiking and the Recreation Opportunity Spectrum. Forest Sci., 2: 405-415.

28. Ustawa lasowa, ustawy Łowickie i Ustawa o ochronie własności polnej, 1887. Lwów, Księgarnia Gubrynowicza i Schmidta.

29. ZajĄC S., Gołos P., LASKOWSKa K., GiL W., ZajĄCZKOWSKi G., 2007. Badania opinii publicznej W zakresie preferencji funkcji lasu oraz określenie zasad jego zagospodarowania i udostępniania dla społeczeństwa w LKP Lasy Warszawskie. Dokumentacja naukowa. Sękocin Stary, IBL.

\section{STRESZCZENIE}

\section{Wartość wodochronnej funkcji lasów}

Słowa kluczowe: badania ankietowe, hydrologiczna funkcja lasów, koszty alternatywne, metoda wyceny warunkowej (CVM)

Często dzieje się jednak tak, że w określonych warunkach, ze względu na charakterystykę otoczenia społeczno-ekonomicznego lub uwarunkowania przyrodnicze, gospodarka leśna musi intensyfikować ilość i/lub jakość publicznych świadczeń lasu, ponosząc koszty ich realizacji. W takich przypadkach z ekonomicznego punktu widzenia należałoby się zastanowić, jaki jest bilans kosztów-korzyści takich działań, innymi słowy ustalić sumaryczną wartość nakładów oraz rzeczywistych lub potencjalnych korzyści (benefis-cost analysis) podjętych zabiegów. $\mathrm{Na}$ podstawie takiego rachunku, w którym niezbędnym elementem jest wartość publicznych świadczeń gospodarki leśnej, można ustalić ekonomiczną efektywność podjętych przedsięwzięć.

W prezentowanej publikacji przedstawiono założenia teoretyczne oraz metodyczne, jak również wyniki wyceny wartości wodochronnej funkcji lasu z wykorzystaniem dwóch metod wyceny: 
1) metody CVM (Contingent Valuation Metod) - metody wyceny warunkowej), która nawiązuje w swoich założeniach metodycznych do teorii użyteczności krańcowej,

2) metody prof. Marszałka - względnej wartości użytkowej (WWU), która należy do tzw. wskaźnikowych metod wartościowania.

Wartość wodochronnych świadczeń lasu, oszacowana z wykorzystaniem metody CVM, wyniosła ponad $86 \mathrm{mln}$ zł. Przeliczając wartość wodochronnej funkcji lasu na jednostkę powierzchni lasów ( 8 864,8 tys. ha - 2000 r.), jeden hektar lasu dostarcza świadczeń wodochronnych o wartości 9,40 zł. Jeśli uwzględnimy tylko powierzchnię lasów państwowych, zarządzanych przez PGL LP (6 953,0 tys. ha Leśnictwo 2001), wartość wzrosłaby do $12,37 \mathrm{zł} \cdot \mathrm{ha}^{-1} \cdot \mathrm{rok}^{-1}$. Jeśli natomiast zostałaby uwzględniona tylko powierzchnia lasów wodochronnych (1 155 tys. ha - Leśnictwo 2001), wartość tego rodzaju świadczeń wyniosłaby $74,41 \mathrm{zł}^{\prime} \cdot \mathrm{ha}^{-1} \cdot \mathrm{rok}^{-1}$.

W metodzie WWU wartość wodochronnych świadczeń lasów (w lasach PGL LP oraz w lasach prywatnych) wyniosła $1177 \mathrm{mln} \mathrm{zł} \mathrm{-} 684 \mathrm{zł} \cdot \mathrm{ha}^{-1} \cdot \mathrm{rok}^{-1}$ (tylko lasy wodochronne). Ze względu na duże różnice wartości produkcji surowca drzewnego w lasach państwowych oraz w lasach prywatnych wystąpiła również duża różnica W wartości świadczeń wodochronnych. W lasach państwowych wartość funkcji wodochronnej wyniosła $805 \mathrm{z} \cdot \mathrm{ha}^{-1} \cdot \mathrm{rok}^{-1}$, natomiast $\mathrm{w}$ lasach prywatnych tylko $146 \mathrm{z}^{\prime} \cdot \mathrm{ha}^{-1} \cdot \mathrm{rok}^{-1}$.

Przedstawione wyliczenia są wartościami szacunkowymi, choć obrazują znaczenie ekonomiczne funkcji wodochronnej. Zastosowane metody mają odmienne podstawy teoretyczne oraz metodyczne, dlatego też uzyskane wyniki są zróżnicowane, choć powinny być zbliżone, ponieważ określone dobro $\mathrm{w}$ danej chwili i określonych warunkach posiada jedną wartość. Jest to z pewnością duża niedogodność stosowanych metod, choć jej źródło nie tkwi w samych metodach, lecz w cechach publicznych dóbr i usług lasu i gospodarki leśnej.

Reviewers:

Assist. prof. Lech Plotkowski

Prof. Stanistaw Zajac 